\title{
Multicultural Education and Approaches to Teacher Training
}

\author{
Yasemin Acar-Ciftci ${ }^{1}$ \\ ${ }^{1}$ Child Development, Istanbul Yeni Yuzyil University, Istanbul, Turkey \\ Correspondence: Yasemin Acar-Ciftci, Child Development, Istanbul Yeni Yuzyil University, 34010, Istanbul, \\ Turkey. E-mail: yasemin.acarciftci@yeniyuzyil.edu.tr
}

Received: March 29, 2019 Accepted: May 27, $2019 \quad$ Online Published: July 12, 2019

doi:10.5539/jel.v8n4p136 URL: https://doi.org/10.5539/jel.v8n4p136

\begin{abstract}
Turkey exposed to several mass immigration movements due to its location, is not a "transit country" anymore for immigrants, but a "target country". Since the day that the migration flows have started, Turkey developed various policies regarding the education of immigrant children. And by the year 2016, these children have begun to be included in the Turkish education system. Research findings reveal that immigrant children face the number of challenges in their education life. These problems include communication and discrimination problems arising out of language and cultural differences. Many countries exposed to mass immigration movements in the world often use multicultural education approaches to solve the educational issues of newcomers. Therefore, comprehensive literature research is needed and that this research will be useful to see the subject as a whole. The findings of the study revealed that the three basic approaches to teacher education could be defined in six stages, each of which consists of two phases. The educators of teachers and policymakers can examine these approaches and evaluate the strengths and weaknesses of each of them based on their philosophical stances about multiculturalism.
\end{abstract}

Keywords: conservative, liberal, critical multicultural education, social justice, teacher training

\section{Introduction}

Along with the developments in industrialization, globalization and information technologies, the characteristics of the geographies in which the countries are located brought paradigm shifts in many of the structures in which education also took place (Ministry of National Education (MoNE), 2017). The geographical position of Turkey is still one of the most important elements that determine its social structure. Today's society is primarily influenced by the migration movements of the 19th and 20th centuries (GIGM, 2015). Turkey exposed to several mass migration movements due to its location, is not a "transit country" anymore for migrants but a "target country" (GIGM, 2017).

According to United Nations High Commissioner for Refugees (UNHCR, 2017) statistics, the number of registered refugees in Turkey including Iraqis, Afghans, Iranian, Somalian and others-apart from Syrian refugees - was 306,791 by March 2017. Children who are 18 or below constitute approximately $35 \%$ of this number, which is 99,025 individuals; and 74,977 of these are school-age children (Manap-Kırmızıgul, 2017). By the date of 20 December 2018, the number of Syrian refugees living in Turkey almost 3,618,624 (Association for Refugees, 2018). Children who are $0-18$ years old constitute $1,723,473$ of this number, and among these $1,138,192$ of them are school-age children. According to the given data, Turkey has been hosting 1,213,169 school-age registered refugee children who are under temporary protection. Since the day that the migration flows have started various policies have been developed in Turkey regarding the education of these children. By the year 2016, these children have started to be included in the Turkish education system (MoNE, 2016).

However, the research studies conducted in the field reveal that these children who are included in the education system face a number of problems during their education. These problems include communication and discrimination problems stem from language and cultural differences (Erdem, Kaya, \& Y1lmaz, 2017; Levent \& Cayak, 2017; Mercan-Uzun \& Butun, 2016; Saglam \& Ilksen-Kanbur, 2017), unwillingness of public school teachers to have refugee students in their classrooms (Erdem et al., 2017; Levent \& Cayak, 2017; Mercan-Uzun \& Butun, 2016), discriminative attitude and behavior that can be displayed by Turkish students and teachers (Istanbul Bilgi University, Child Studies Unit, 2015; HRW, 2015), communication problems among students, language problems, and problems that arise from cultural differences and differences between value judgements 
(Erdem et al., 2017).). Besides, the data on the attendance of children who are under temporary protection to school demonstrates that the attendance rates decrease with an increase in the education levels. The schooling rates of students who receive education in official schools and temporary education centers have occurred as; preschool $39.02 \%$, primary school $87.80 \%$, secondary school $50.74 \%$ and high school education $22.40 \%$ (MoNE74, 2018). Among the primary reasons for early school dropout are economic problems, and other problems such as early marriages, language and cultural differences among students. Besides, uncertainty about the future, rejection of Turkish parents for teachers and school administrators to let foreign students in schools, discriminative attitudes, and behaviors confronted in schools (Tastan \& Celik, 2017) play important roles on school dropout. Furthermore, teachers are frequently disturbed by the existence of Syrian children in their classrooms, display negative behaviors, and do not act proactively to include these children into in-class activities (Tastan \& Celik, 2017). Some teachers and administrators stated that teachers who are not trained to work with children from different cultures do not consider themselves competent and think that they are not capable of making a positive contribution to the development of these children (Mercan-Uzun \& Butun, 2016), and therefore require vocational development and support training to work with Syrian children (Kardes \& Akman, 2018; Ozer, Komsuoglu, \& Atesok, 2016).

These problems perceived as 'daily problems' for the time being. However, the average length of stay that refugees spend in host countries is 20 years in 2014, according to the various immigration cases analyzed in the international context. This duration is almost three times more than the length estimated for the early 1990s (Milner \& Loescher, 2011). Moreover, the number of Syrian refugees who have Turkish citizenship is around 79,820 . The number of Syrians who has a residence permit was reported as 32,199 by the date of 25 January 2019 (Association for Refugees, 2018). In the light of this information, it can be predicted that Syrian refugees will receive Turkish citizenship and residence permit ever-increasingly, and stay in Turkey for longer durations or for permanently this context, Turkey requires a comprehensive and long-term education reform which includes all cultural, ethnic and other disadvantaged groups in the system with a particular focus on children and will have significant impacts on social peace and welfare, besides the short-term urgent solution strategies towards all children with temporary protection status. The reform projects that have been implemented from past to present and the international experiences show that the most critical factor in reform efforts in education is the teacher (MoNE, 2017). Creation of consistent curriculums for schools and teacher training programs by means of a shared vision of teachers, educators and academic is one of the ways to make long-term and permanent changes for educating students who can overcome the growing problems. Preparation of a consistent teacher training program requires faculty members to determine a common goal and share collective responsibility and to have an opportunity to make an impact on policies and practices.Many countries exposed to mass immigration movements in the world often use multicultural education approaches to solve the educational problems of newcomers. The reason for this is that multicultural education is a reform approach that aims to solve such problems. It is possible to argue that studies on multicultural education conducted in Turkey date back to fifteen years ago. Although there has been a significant increase in the number of studies conducted on multicultural education, there are few studies related to multicultural teacher education during this period. Therefore, it is essential to focus on comprehensive literature research; therefore, this research will be useful to see the subject as a whole.

This study aims to review previous studies focusing on "multicultural teacher education systematically". For this purpose, the following questions are answered:

1) What is multicultural education, and is there a difference between theory and practice?

2) How has this difference been conceptualized, if any?

3) Is there a difference between this conceptualization and the multicultural teacher education literature in recent years?

\section{Method}

This study aimed to investigate the previous studies related to 'multicultural teacher education approaches' considering their classifications, social objectives, designs, and teacher education objectives. Therefore, a systematic review research method (Millar, 2004) was used to review previous studies conducted focusing on multicultural teacher education approaches. Systematic rules and phases were followed for the critical evaluation of these studies and the analysis of all relevant studies. According to Millar (2004), these phases are a) determination of the objective, b) the selection of studies, which are consistent with the objective founded on particular criteria, and c) drawing inferences from the gathered information. 
An electronic database search, using a variety of Internet search engines, was conducted in November-December 2018: Educational Resources Information Centre (ERIC), SCOPUS, PsychINFO, EBSCOhost, and Google Scholar. The keywords "multicultural teacher education approaches" and "multicultural education approaches" or "analysis, multicultural education" in English were searched. Based on the objective of the research, primarily 107 studies (Appendix A) published between the years 2010 and 2018 were downloaded. The fact that the papers being directly related to "multicultural teacher education approaches" and "multicultural education approaches" was the significant criterion in the selection of documents for this study.

\section{Results}

\subsection{What Is Multicultural Education and Is There a Difference Between Theory and Practice?}

Multicultural education is defined as a medium to eliminate the inequities that students face regarding race, ethnic origin, gender social class, language, sexual orientation, and abilities (Banks \& Banks, 2005; Ukpokodu, 2008), and a general school reform which was designed to increase educational equity among culturally, ethnically, economically, etc. marginalized groups (Banks, 1993; Vavrus, 2002). The concept is considered as a superior discipline due to its content, concepts, principle, theory and paradigms which based on fields such as history, social sciences, and behavioral sciences and particularly on ethnic studies and women studies, and its design as a study field that integrates the given fields (Banks \& Banks, 2001; Vavrus, 2002).

Despite the fact that multicultural education is an educational approach which is designed with the purpose of eliminating existing inequities in the society, it may vary in terms of implementation due to the inclusion of knowledge on different cultures existed in the society in the standard curriculum of the dominant culture, and inclusion of festivals, celebrations (Banks, 2002), different materials, perspectives and pedagogical implementations (Cumming-McCann, 2003). Similarly, it may include a number of possibilities, such as bilingual education or mother tongue-based education (Nieto, 2017). However, such kinds of implementations are considered as partial and superficial (Irvine, 2003; Ladson-Billings, 1999; Villegas \& Lucas, 2002; Zeichner \& Hoeft, 1996) in comparison to a consistent and inclusive multicultural curriculum. The reason for this situation is the idea that an approach to education that does not have the purpose of changing the "power relations between majority and minority groups" cannot bring about equity and justice in the real sense (Solomon, 1996, p. 72).

\subsection{How Has This Difference Been Conceptualised if Any?}

The leaders of the field who have been examining a number of studies on multicultural education, which has diverse implementations, have presented conceptual/theoretical approaches towards the meaning and implementation of multicultural education. These approaches are also known as phase approaches and include the most well-known approaches of McLaren (1994; 2003), Grant and Sleeter (1987; 2007), and Banks (2004; 2012) Jenks, Lee and Kanpol (2001) that base their opinions within the framework of McLaren's $(1994 ; 2003)$ theoretical framework on multiculturalism, define the concept of teacher training within three conceptual frameworks (Table 1) as conservative, liberal and critical (Jenks et al., 2001; McLaren, 1994; 2003; Webster, 1997). 
Table 1. Multicultural education and approaches to teacher education (Jenks ve ark., 2001)

\begin{tabular}{|c|c|c|c|}
\hline Mclaren (1994) & Grant ve Sleeter (1987) & Banks (1994) & Objectives of Schools \\
\hline $\begin{array}{l}\text { Conservative } \\
\text { Multiculturalism }\end{array}$ & $\begin{array}{l}\text { Teaching exceptional } \\
\text { and culturally different }\end{array}$ & & $\begin{array}{l}\text { Conservative multiculturalists ignore the importance of difference } \\
\text { in favor of an ideology of cultural homogeneity. Schools } \\
\text { assimilate students into the mainstream culture and its attending } \\
\text { values, mores, and norms (Jenks ve ark., 2001). }\end{array}$ \\
\hline $\begin{array}{l}\text { Liberal } \\
\text { Muliculturalism }\end{array}$ & Human Relations & $\begin{array}{l}\text { Contributions } \\
\text { Additive }\end{array}$ & $\begin{array}{l}\text { Attempts to promote acceptance of diversity through intergroup } \\
\text { education based on the sharing of feelings and values—a liberal } \\
\text { agenda based on the goal of culturally different students living } \\
\text { together harmoniously (Grant \& Sleeter, 1987; Jenks ve ark., } \\
\text { 2001). }\end{array}$ \\
\hline \multirow[t]{3}{*}{$\begin{array}{l}\text { Critical } \\
\text { Multiculturalism }\end{array}$} & Single-group studies & & $\begin{array}{l}\text { With the goal of increasing the status of the group, single-group } \\
\text { studies endorse education that develops a critical consciousness } \\
\text { in students regarding the need for change for the identified group } \\
\text { (Jenks ve ark., 2001). }\end{array}$ \\
\hline & Cultural pluralism & & $\begin{array}{l}\text { Rather than being limited to the study of particular minority } \\
\text { groups, the goal is to reduce prejudice by helping students adapt } \\
\text { to as much diversity as possible and to learn the importance of } \\
\text { power equity and social justice for all groups (Jenks ve ark., } \\
\text { 2001). }\end{array}$ \\
\hline & Social reconstructionist & $\begin{array}{l}\text { Transformation } \\
\text { Social Action }\end{array}$ & $\begin{array}{l}\text { The curriculum teaches social action skills, promotes cultural } \\
\text { pluralism and alternative lifestyles, and has students analyze } \\
\text { oppression with the intent of eventually, if not immediately, } \\
\text { taking action to work for a more democratic society (Jenks ve } \\
\text { ark., 2001). }\end{array}$ \\
\hline
\end{tabular}

\subsection{Is There a Difference Between This Conceptualisation and the Multicultural Teacher Education Literature in Recent Years?}

\subsubsection{Conservative Multicultural Education}

The traditional perspective in education is generally defined as "conservative multiculturalism". The concept of conservative multiculturalism considers multiculturalism as an aspect that divides society and argues that the dominant culture and its values, traditions, and norms should be adopted (Grant \& Ham, 2013). Conservatives are primarily concerned with the rapid transmission of culture based on the continuity of existing social order by regarding knowledge as constant (Banks, 1994; Banks \& Banks, 2012).

Nieto $(1994 ; 2017)$ defines conservative multicultural education as "a situation in which school structures, policies, curricula, instructional materials, and even pedagogical strategies are primarily representative of the only dominant culture" (p. 250), and expresses the concept as monocultural education. According to Nieto, in this approach, teachers are proud of the fact that they are "color-blind", that is, that they see no differences among their students, treating them all the same (Nieto, 1994; 2017). It is assumed that cultural differences have no vital role in success, and the commitment of all students to the same academic standards is considered as the basis (Jenks et al., 2001). The first phase of conservative multicultural education is to prepare teachers to enable students to be assimilated in the education system based on the assumption that there are no cultural differences among students.

The approach "teaching the exceptional and culturally different," which takes the first place in the division of Sleeter and Grant $(1987 ; 2007)$ is considered within the scope of conservative multiculturalism. In this approach, which includes disabled students besides the different students (Leistyna, 2002), the primary purpose of the curriculum is to fill the gaps in terms of basic knowledge, skills and values that constitute an impediment for working in a better paid job (Jenks et al., 2001), and to facilitate the learning of language of the dominant culture (Grant \& Ham, 2013). The purpose of school is teaching the traditional mediums of instruction and bridging between different cultures and the dominant culture (Grant \& Sleeter, 2007; Grant \& Ham, 2013; Leistyna, 2002; Sleeter \& Grant, 1987), and the social purpose of school is to facilitate the assimilation process of students into the dominant society (Grant \& Ham, 2013).

Gorski (2009), who assessed the multicultural educational implementations of teacher training in the USA through lecture programs, places the first phase of the five-phase approach which is the teaching of others in the conservative approach. This approach is characterized by the use of marginalizing language, presentation of the society as a homogenous structure, and assessment of education from a market-based or capitalist approach. 
According to Gorski, marginalizing language defines an individual or a group apart from the normality sphere and leads to the maintenance of hegemony and adds negative value to identities and ideologies which are different from the hegemonic norm.

In the context of integration of multicultural content into curriculums, Banks presented a four-phase approach consisted of the phases titled contributions, additive, transformation and social action (Banks, 1994; Banks \& Banks, 2012). In this line, the contributions approach is assessed in the scope of the conservative approach by Gorski (2009). However, Jenks et al. (2001) indicated that the contributions approach includes both traditional and liberal components. Indeed, the contributions approach presented by Banks, and the tolerance approach presented by Nieto $(1994 ; 2017)$ include both conservative and liberal elements.

As is evident from its name, the contributions approach expresses inclusion of the contributions of the groups which are excluded from the dominant culture to a curriculum and maintaining the basic structure, objectives and main characteristics of the curriculum of the dominant culture without any alteration. This approach is characterized by the placement of female and male characters of ethnic culture and cultural pieces into a curriculum by employing criteria that are used in the placement of female and male characters of the dominant culture into a curriculum (Banks \& Banks, 2012). However, due to the fact that different groups are regarded as an addition, students are not allowed to develop a global perspective towards ethnic and cultural groups. Furthermore, the contributions approach does not address issues such as oppression, unjust treatment, racism, or poverty. This approach which does not address the issues of inequities and discrimination as well remains limited to minority groups and reinforces the judgments and misconceptions (Banks, 1988). Conservatives who advocate this approach argue that minority groups are represented in instruction programs, and students are informed about other cultures (Jenks et al., 2001).

Schools that are at a higher level in comparison to monocultural schools accept differences in the condition of altering them. However, because assimilation is still the ultimate goal, language and culture related differences are changed rapidly. This ideology also reflects on the physical environment, attitudes of the personnel, and the curriculum which students are exposed to (Nieto, 1994; 2017).

The ideological roots of the conservative multiculturalism have their origins in the market logic. Therefore, in the conservative multiculturalism approach, the equity and excellence objectives are based on the participation of students into the free market competition, luck, the ability to survive among the best and an upward social movement (Jenks et al., 2001).

In this context, the second phase-teacher training objective of the conservative multiculturalism approach is to prepare teachers to analyze cultures, values, lifestyles, and worldviews of different identity groups, and eventually to assimilate them into the education system.

\subsubsection{Liberal Multicultural Education}

The liberal multicultural approach considers all ethnic and racial groups naturally equal and intellectually "same" (McLaren, 1995; 2003). Liberal multiculturalism that originates from respecting cultural and ethnic differences also supports cultural sensitivity and celebrates cultural traditions in the context of curriculums and instruction (Banks \& Banks, 2012).

Liberal multiculturalism is based on the human relations approach have foreign, which recognizes cultural diversity and pluralism and accepts and celebrates differences (Grant \& Sleeter, 2007). The social purpose of the human relations approach is to encourage unity, understanding, and acceptance within social structures. On the other hand, the purpose of the school is teaching the necessary skills, developing positive emotions among students, forming a positive self-identity and reducing stereotyped biases (Grant \& Ham, 2013; Leistyna, 2002). In this approach, it is believed that the primary issue of multicultural education is an interpersonal rapport and improvement of emotions and communication in a classroom and school is aimed at "reducing biases" (Grant \& Sleeter, 2007). Therefore, a curriculum should include basic academic courses, and also courses on individuals' differences and similarities (Grant \& Ham, 2013). The "human relations" approach developed by Grant and Sleeter, which is included in the liberal multicultural education approach, is compatible with the "additive approach" which was developed by Banks regarding the integration of multicultural content into curriculums (Jenks et al., 2001). The additive approach expresses the main structure of a curriculum, and the addition of ethic content, concepts, themes, and perspectives into a curriculum without altering any characteristics. This approach which requires a considerable amount of time, effort and education causes to the addition of an ethnic content into a curriculum without considering the objectives, goals, and nature of the particular curriculum (Banks, 2004). The use of 'teaching the exceptional and culturally different approach' in the scope of both human relations approach and teacher curriculums presents a supportive characteristic in terms of teachers' adoption of a compensatory 
perspective towards accepting languages spoken at home and the ones who learn a second language apart from the language spoken at home. Moreover, both approaches were designed to facilitate the process of transition for students in terms of the dominant language and culture (Grant \& Ham, 2013).

In the classification of Gorski (2009), liberal multicultural education is addressed in two phases as tolerance and teaching with multicultural sensitivity and teaching with multicultural competence. In the phase of tolerance and teaching with multicultural sensitivity; respecting diversity, sensitivity to cultures and self-reflection are emphasized; however, the educational inequities are not mentioned. Respecting diversity is included in an assimilationist pluralist approach (Gorski, 2009). In this approach, students have an opportunity to analyze their assumptions, biases, and values (both negative and positive), and the impact of these factors on interpersonal relations. In this way, the approach aims to enable students to develop a cultural understanding. The lectures are generally organized based on the identity aspect (race, gender, class, etc.), and students focus on their prejudices and biases.

The human relations approach provides the skills of tolerance and sensitivity to differences through analyzing the first phase of the liberal multicultural education that includes tolerance, teaching with cultural sensitivity and additive approaches and their teacher training objectives in terms of biased attitudes and behaviors.

The teaching with the multicultural competence phase of Gorski (2009) and the tolerance phase of Nieto (1994; 2017) are consistent with each other. In this sense, the inclusion of these phases in the second stage of liberal multicultural education would be appropriate. The multicultural competence phase in teacher training puts multicultural competences in the center and aims at providing "cultural competence" by teaching culturally sensitive learning and teaching strategies, however, the phase overlooks educational inequities.

On the other hand, in the "acceptance" phase of Nieto $(1994 ; 2017)$, the value of differences is neither acknowledged nor underestimated. At this level, a perspective and movement towards multicultural education are observed. Various school politics and implementations alter as an indication of this movement, and assimilation is no longer considered as an objective. to enable teachers focusing on the concept of diversity seminars on diverse subjects such as learning styles, unbiased evaluation techniques, and bilingual education are provided. Liberal multicultural education requires to adapt instruction styles, learning strategies, and communication between school and parents to curriculums (Grant, 1994).

In this approach, equity and excellence are achieved in education through acceptance, tolerance, and understanding. Just like the conservative approach, the liberal approach assumes that laws and political decisions will bring about equity and excellence within the dominant culture and free market economy (Jenks et al., 2001). Despite the fact that the intention of this approach is humanist and utilitarian, it still masks controversies and conflicts in society by ignoring identity-related problems revolving around issues such as race, ethnic origin, and class (Jenks et al., 2001). The teacher training objective of the given phase of the liberal multicultural education is equipping prospective teachers with the knowledge, implementation skills and pedagogical strategies that are necessary for implementing multicultural curriculums (Gorski, 2009).

\subsubsection{Critical Multicultural Education}

Critical multiculturalism focuses on the issues of culture, race, socioeconomic class and gender, and emphasizes transforming structural and social relations. In this approach, cultures are not considered as compatible with each other due to conflicts of interest (McLaren, 1994; 2003). It is argued that intercultural harmony can be achieved only through a commitment to social justice (Gay, 2000; Nieto \& Bode, 2008). On the one hand, critical approaches search for justice by focusing on the relationship between equity and excellence; and on the other hand, by focusing on race, ethnic origin, and class divisions. The approach accepts that leaving these components to the free market competition and upward social movement process will not bring about justice (Jenks et al., 2001). Critical multiculturalists question the existing socio-political order due to their belief in the presence of significant social inequities and injustices, and accordingly, analyze the historical and political contexts of curriculums. According to critical multiculturalists, societies do not fulfill their responsibility of providing equal opportunities for everyone (Gamage, 2008). Therefore, critical multiculturalists argue that the purpose of education is development and democratic emancipation, and schools, curriculums, and instruction are mediums for producing democratic citizens (Gamage, 2008). The acceptance that cultural pedagogy which is expressed with schools and television shows, movies, video games, popular music, etc. does not engage in unbiased and ideologically immaculate activities is at the center of the critical theory (Gamage, 2008; Kincheloe \& Steinberg, 2002). In the critical approach, justice is pursued by focusing on the relationship between equity and excellence, and on the other hand, on race, ethnic structure, and socioeconomic group structures. It is believed that leaving these problems to free market competition processes and only to upward social movement would be a failure in terms of 
realizing justice (Jenks et al., 2001). Critical multicultural education provides a pedagogic framework that puts, ideas, experiences and social norms, that certain groups benefit from at the expense of others, in the center of educational studies to criticize and object, which is strengthening and transformative for students (Gérin-Lajoie, 2008; Ghosh, 2002; Kincheloe \& Steinberg, 2002; May \& Sleeter, 2010; Solomon, 1996).

The present study addresses the "single group studies" and "multicultural education," and "multicultural social justice" approaches of Sleeter and Grant within critical multiculturalism. Single group studies focus on a particular group and aim to explain why this group is exposed to discrimination (Sleeter \& Grant, 1987; 2007). The objectives of these studies and ethic research programs include; (a) content integration that presents ideas and concepts by providing examples on members of different groups or information about different groups (b) efforts of a group member to gain economic, social and political power. These strategies concentrate on the knowledge production process towards the questions of why perspectives of a certain group are excluded, what are the reasons for inequity, and how traditional education maintains inequity (Ali \& Ancis, 2005). Single group studies approve an education towards developing a critical awareness of the need for change in the group, in order to increase the status of the particular group (Jenks et al., 2001). The social purpose of this approach is to recognize the groups that students who are excluded from the dominant culture belong to and to teach them their roots through critical questioning in a way to support structural equity. The purpose of the school is to teach the skills which are necessary for a group to reach their objectives through history and culture. A curriculum includes appropriate learning experiences and activities that will enable students to learn about the constitutions of their group to society, challenges that groups should overcome, and the issues that they currently confront (Grant \& Ham, 2013).

The advocates of the second critical approach presented by Grant and Sleeter, "multicultural education" use the expression of multicultural education to define human rights, social justice, equal opportunity, cultural diversity, and equal power distribution methods for marginalized groups (Ali \& Ancis, 2005; Grant \& Sleeter, 2007). The social purpose of this approach is to help students to learn about their roots through intellectual reasoning and critical questioning in a way to support their pluralist perspective with structural equality, cultural pluralism, and cultural recognition. The objectives of the school include the acceptance of power equity between groups, equality of opportunity, cultural pluralism, and alternative lifestyles. A curriculum should be organized around the contributions and perspectives of multiple groups, to teach critical thinking for the analysis of similarities and differences. Curriculum activates designed in a way to support students for the subjects which academically challenge them and for the use of multiple languages (Grant \& Ham, 2013). It integrates knowledge on various groups into the curriculum, and in this way, enables the continuous teaching of all subjects from a multicultural perspective (Ali \& Ancis, 2005; Grant \& Sleeter, 2007). Also, this approach aims to alter school culture and organization to enable students to represent and enhance their groups. The "multicultural social justice" approach of Grant and Sleeter is expressed as the most visionary and critical approach which follows the multicultural education phase. In multicultural social justice education, the issues related to race, social class, gender, and disability are addressed more directly in comparison to other approaches. The purpose of this approach is to prepare the citizens of the future, particularly colored, poor, women and disabled individuals, to take action to serve the interest of all human groups in a better way. The approach is based on the re-structuring idea that aims to restructure the society for more equality in terms of race, class, gender, and disability, and also questions the power relations and ethics in the global economy (Grant \& Sleeter, 2010). Despite the fact that this approach and the multicultural education approach are very similar concerning their curriculum and instruction, there are differences due to the fact that the four practices are intrinsic to multicultural social justice education (Grant \& Sleeter, 2010). First of all, democracy is actively implemented in schools (Banks, 2007; Parker, 2003). Secondly, students learn about how to analyze institutional inequality in their own living conditions. Thirdly, students learn about participating in social actions to change unjust social processes. Finally, they might collaborate to extend their common interest spheres formed between marginalized groups. Therefore it is important as it can provide energy against oppression and strengthen the fight against unjust social processes.

In his study, Gorski (2009) mentions two important phases. These are "teaching in sociopolitical context" that has become critical in the context of multiculturalism and "teaching as resistance and counter-hegemonic practice." Teaching in the sociopolitical context is characterized by the critical analysis of education policies and practices at an institutional level, addressing this analysis within a wide sociopolitical context and contribution of critical theories. This approach emphasizes the analysis of the impacts of sociocultural and sociopolitical variables on race, ethnic origin, gender and social class, and the impacts of tendencies of schools' structures, policies, and practices concerning the maintenance of discrimination and inequity on students and educators. Furthermore, the attention is drawn to the parallelism between educational inequalities and social inequalities. The significant difference between the "teaching as resistance and counter-hegemonic practice" and "teaching in sociopolitical context" is 
preparing teachers for resistance, and their determination to make their students for strength. Moreover, this approach aims to enable teachers and prospective teachers to imagine themselves as a change agent within and outside schools and to nurture this spirit in their students; and brings forward the issue of reconstruction of the society as the key project of multicultural education.

When the concept of multiculturalism is considered as the basis, the "transformation" and "social action" phases of Banks' (1994; 2012) and the respect" and "affirmation, solidarity and critique" phases of Nieto (1994; 2017) becomes more critical. The transformation approach of Banks is different than contributions and additive methods in principle. In the transformation approach, there is a need for a change in the structure of the curriculum due to the fact that perspectives and experiences of ethnic, racial and other minority groups will be included in the curriculum. The transformation approach alters the underlying assumptions of the curriculum and proposes reform to enable students to consider concepts, subjects, themes, and problems from different ethnic perspectives and viewpoints. First of all, the transformation approach is critical because it teaches students to analyze the knowledge that underlies cultural assumptions and its relation between different cultures and the dominant culture. It encourages democracy through equity and justice education. In this way, it enables students to comprehend concepts from different perspectives (Banks, 1994; 1988; 2012). On the other hand, the social action approach requires students to take action to fight injustice and inequity through community-based curriculums, instead of analyzing problems through a restructured curriculum in the transformation phase. By means of this curriculum, students carry out research/action projects and learn about the methods to start a change (Banks, 1994; 1988; 2012).

In Nieto's $(1994 ; 2017)$ classification, the "respect" phase follows the affirmation phase. This phase includes respecting differences and esteem for diversity. When the differences are respected, respect has become the basis of all activities that occur in a school. The employees of a school, teachers and other personnel, also show a diversity just as students. Major changes can be realized in the curriculum, and bilingual education can be included in curriculums (Nieto, 1994; 2017). In the "affirmation, solidarity and critique" phase, which follows the respect phase, the main assumption is based on the understanding that culture is not constant or unalterable, and therefore it is reproachable. The multicultural education at this level is associated with equity and social justice. Students start to understand the universality of power, oppression, prejudice, and privilege, to see the connection between themselves and others, and to develop a global understanding of social movements.

Accordingly, it is possible to place the approaches within the scope of multicultural education in Sleeter and Grant's (1987; 2007) single group studies and multicultural education, Banks's (1994; 2012) transformation, Gorski's (2009) teaching in sociopolitical context and Nieto's (1994; 2017) respect approach in the first phases of critical multicultural approaches. The main purpose of teacher training objective of this phase is to equip them with skills to improve their students' social action skills by engaging in a critical examination of the systemic influences of power, oppression, dominance, inequity, and injustice on schooling, from their practice to institutional and federal education policy.

The phases; Grant and Sleeter's (1987; 2007) multicultural social justice, Gorski's (2009) teaching as resistance and counter-hegemonic practice, Nieto's affirmation, solidarity, and critique phases and Banks's social action phases constitute the second phase of critical multiculturalism. Critical theories are concerned with the role of institutions such as schools in the prevalence of economic, social and political inequity, and they acknowledge that these inequities and exploitation is not only economical, but also arise from gender, race, nationality, social class structures and discrimination against disabled individuals, apart from (Hooks,1994; Mthethwa-Sommers, 2014). The teacher training objective of this phase is to equip teachers with the creating research/action projects skill that will help them to enable their students to take action and fight against injustice and inequity through community-based curriculums.

As a result the present study re-organized the approaches to teacher training and teacher training objectives of these approaches within the framework of McLaren's (1994; 2003) conceptual framework by considering the main features of the approaches presented by Grant and Sleeter (1987; 2007), Nieto (1994; 2017), Banks (2004; 2012) and Gorski (2009) (Table 2). 
Table 2. Multicultural education and approaches to teacher education

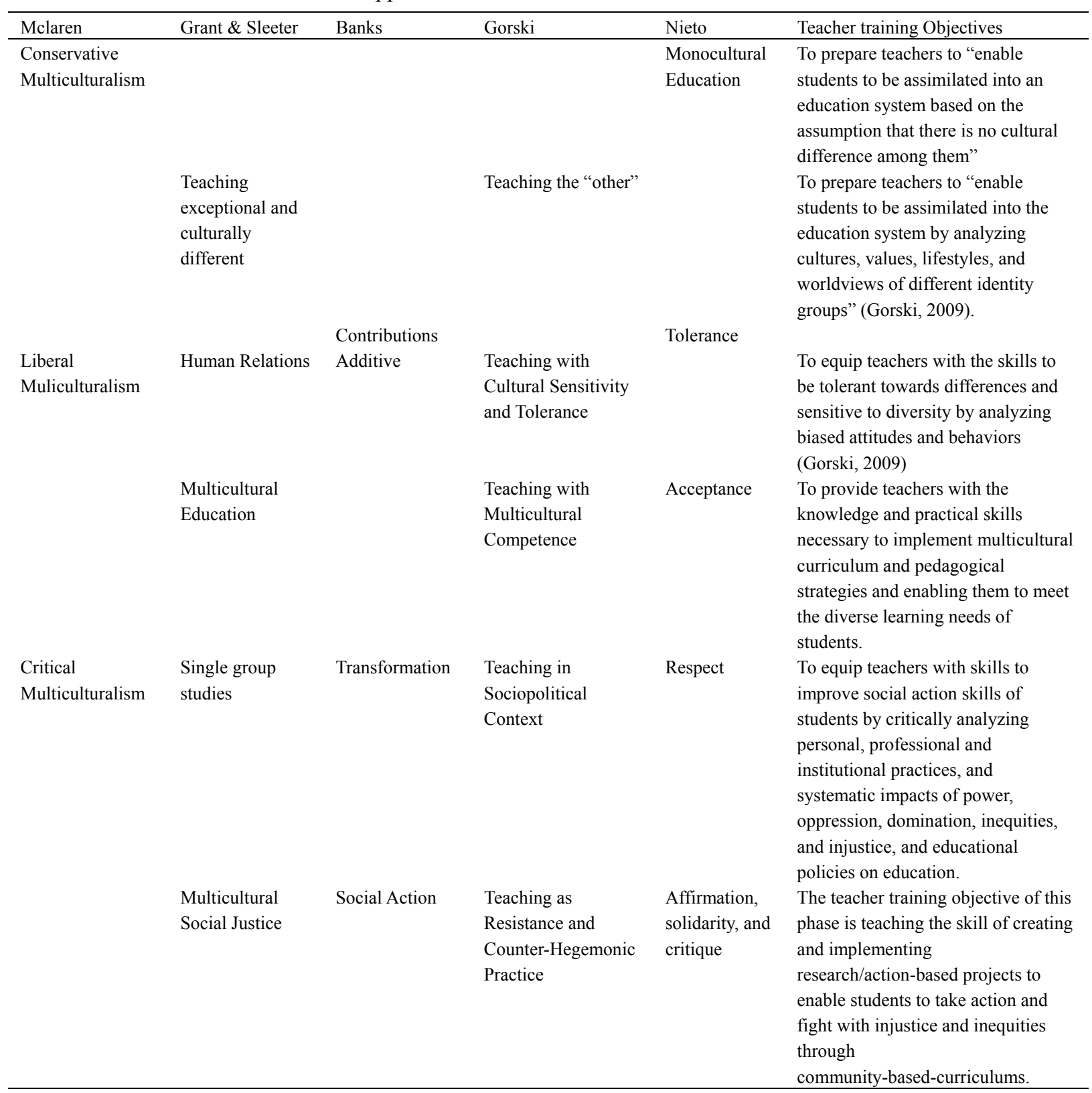

\section{Discussion}

Data of the study, which are intended to see the whole, reveals the socio-political context of multicultural education and teacher education in the United States and how it is defined. The studies, in particular the study of Gorski (2009), conducted in the field reveal that all of the liberal and critical approaches starting from the conservative multicultural education and the in-between tones are used in teacher education today, even in the mother country of multicultural education, and that there is no collective voice in this field.

The social conditions of each country are different from each other. However, multicultural education refers to more than just one set of teaching strategies or teaching programs; it is also seen as an arena (Sleeter, 2018) for the power of defining the objectives and processes of education in a diverse and unequal world. In this sense, it is almost the same in every country today. The determinant factor in this field is the cultural, social, political, and economic philosophies of the countries. The cultural politics history of Western societies is closely related to the development of their societies as a nation-state. These societies have especially assumed a central responsibility in the process of establishing a centralized state by defining a community or a tribe living in a particular region as a specific culture. They, as members of a defined society (nation) living on the same land, have helped the 
"imaginary societies," as expressed by Benedict Anderson, form a nation that is shaped jointly by common identity and history and that shares a common culture (Bennett, 2001, p. 27). Just as it is all over the world, naturally the process was the same in Turkey as well, and the known facts have not been officially stated. For this reason, it is seen in Turkey that very few studies, for which research results are shared with the public, about the distribution of various groups are conducted by some private survey companies. According to the data of the survey conducted with mother tongue control in 2011, the distribution of ethnic identities of adults (18 years old and over) in Turkey has been determined to be local identities with 78.1 percent Turkish, 13.4 percent Kurdish, 1.5 percent "Laz" and "Turkmen" and other groups with 0.31 percent (Konda, 2011). According to this distribution, there were rarely a few students from different cultures in the classes of teachers, and they could not perceive that those students came from different cultures. Because they were being prepared to "ensure the assimilation of such students in the education system, based on the assumption that there was no cultural difference between the students." An essential part of these children could not survive in the education system for a long time. Today, the schools and teachers encountered such a large group for the first time, and they don't know what to do, how to educate these children; they don't understand them and cannot speak their languages. This is a major problem now not only for the teachers and schools, but also for the education system and, even, for all systems and society. In such contexts, multicultural education is generally considered as a way of improving the conditions and assimilation of new immigrants (Aguado-Odina et al., 2017; Sleeter, 2018) and as a way to create "tolerance" between immigrants and native students. According to the results of this study, the objective of teacher education of the second phase of conservative multicultural education is to examine the cultures, values, lifestyles, and worldviews of various identity groups and to prepare the teachers in order to assimilate those various identity groups in the education system (Gorski, 2009). This may be considered as an option; however, it may mean creating new and bigger problems rather than a solution when we look at the experiences of the Kurdish community in Turkey and the communities in the world.

In this study, it is seen, through the examination of biased attitudes and behaviors and prejudices in particular, that the teacher education objectives of liberal multicultural education approach are to provide teachers with the ability to tolerate differences and be sensitive to diversity (Gorski, 2009) and to provide them with the knowledge and practical skills necessary to implement the multicultural education program and pedagogical strategies and to ensure that students meet various learning needs. The liberal approach that can be defined as more humane compared to conservative multicultural education requires a new philosophical view and the reconceptualization of multicultural education, as in other approaches. Such an approach towards teaching is very different from assuming that a contextually unbiased general pedagogy and curriculum is suitable for all students. Many educators of teachers and policymakers may consider such approach and conceptualization sufficient and suitable.

It is recommended that the necessity of social change and teacher education can be organized in line with these objectives by taking social justice as the foundation in both phases of critical multicultural education. It is seen in literature in recent years that the emphasis on "social justice" as a theme in the teacher education concept has increased. According to Cochran-Smith, Gleeson, and Mitchell (2010), some critics (i.e., Crowe, 2008; MacDonald, 1998; Will, 2006) reject the idea of "teacher education for social justice" because they see it as progressive and political targets at the cost of traditional academic learning objectives. On the contrary, many supporters (i.e., 2006; Michelli \& Keizer, 2005; Oakes \& Lipton, 1999) argue that providing all students with intellectually complex learning opportunities is a central part of teacher education for social justice (Cochran-Smith et al., 2010).

The educators of teachers and policymakers will evaluate the strengths and weaknesses of each of them based on their own philosophical stances about multiculturalism while examining the approaches mentioned above. Ideally, it can be asserted that a fairer and more democratic society can be achieved by the realization of the teacher education objective of the final stages, by moving the students towards a critical philosophical framework and through a fair and democratic education.

\section{References}

Ali, S. R., \& Ancis, J. R. (2005). Teaching and social justice: Integrating multicultural and feminist theories in the classroom. In C. Z Enns \& A. L Sinacore (Eds.), Multicultural education and critical pedagogy approach. (pp. 69-84). Washington: American Psychological Association. https://doi.org/10.1037/10929-004

Association for Refugees/Multeciler Dernegi. (2018). Istatistikler. Retrieved from https://multeciler.org.tr/istatistikler/ 
Banks, J. A., \& Banks, C. A. (2012). Multicultural education: Issues and perspectives (8th ed.). Wiley Global Education.

Banks, J. A., \& Banks, C. A. M. (2004). Handbook of Research on Multicultural Education. 2.bs. Multicultural education: Historical development, dimensions, and practice (pp. 3-30). San Francisco USA: Jossey-Bass Edition. https://doi.org/10.2307/1167339

Bennett, T. (2001). Differing Diversities Transversal Study on the Theme of Cultural Policy and Cultural Diversity. Council of Europe Publishing, F-67075 Strasbourg Cedex ISBN 92-871-4649-7.

Clumming-McCann, A. (2003) Multicultural education: Connecting theory and practice. Focus on Basics: Connecting Research and Practice, 6(B), 9-12. Retrieved from http://ncsall.net/index.html@id=208.html

Cochran-Smith, M., Gleeson, A. M., \& Mitchell, K. (2010). Teacher education for social justice: what's pupil learning got to do with it? Berkeley Review of Education, l(1). https://doi.org/10.5070/B81110022

Erdem, M. D., Kaya I., \& Yilmaz, A. (2017). Örgün Eğitim Kapsamındaki Suriyeli Çocukların Eğitimleri Ve Okul Yaşantıları Hakkında Öğretmen Görüşlerinin Değerlendirilmesi. International Journal of Languages' Education and Teaching, 5(3), 463-476. https://doi.org/10.18298/ijlet.2071

Gamage, S. (2008). Interrogating common sense: Teaching for social justice In I. Soliman (Ed.), Current thinking about critical multicultural and critical race theory in education (pp. 111-131). Frenchs Forest, Australia: Pearson Education.

Gay, G. (2000). Culturally responsive teaching: Theory, research, and practice. New York: Teachers College Press.

GİGM. (2017). Göç İdaresi Başkanlı̆g. The Directorate General of Migration Management. Geçici Koruma. Retrieved from http://www.goc.gov.tr/icerik6/gecici-koruma_363_378_4713_icerik.

GİGM. (2015). Göç İdaresi Başkanlığı. The Directorate General of Migration Management. Turkiye'nin Duzensiz Gocle Mucadelesi. Retrieved from http://www.goc.gov.tr/icerik3/turkiyenin-duzensizgocle-mucadelesi_409_422_424

Gorski, P. C. (2009). What we're teaching teachers: An analysis of multicultural teacher education coursework syllabi. Teaching and Teacher Education, 25, 309-318. https://doi.org/10.1016/j.tate.2008.07.008

Grant, C. (1994). Best practices in teacher preparation for urban schools: Lessons from the Multicultural teacher education literature. Action in Teacher Education, 16(3), 1-18. https://doi.org/10.1080/01626620.1994.10463204

Grant, C., A., \& Ham, S. (2013). Multicultural Education Policy in South Korea: Current Struggles and Hopeful Vision. Multicultural Education Review, 5(1), 67-95. https://doi.org/10.1080/2005615X.2013.11102898

Grant, C., \& Sleeter, C. (2007). Doing multicultural education for achievement and equity. New York: Routledge.

Grant, C., \& Sleeter, C. (2008). Turning on learning: Five approaches for multicultural teaching plans for race, class, gender, and disability. San Francisco: Wiley \& Sons, Inc.

Grant, C., \& Sleeter, C. (2010). Race, Class, Gender, and Disability in the Classroom, In Multicultural education: Issues and perspectives (Ed. Banks \& Banks, 8th ed.). Wiley Global Education

Hooks, B. (1994). Teaching to transgress: Education as the practice of freedom. NY: Routledge. https://doi.org/10.3366/para.1994.0013

Irvin, J. J. (2003). Educating Teachers for Diversity: Seeing with a Cultural Eye. Teachers College Press.

Jenks, C., Lee, J. O., \& Kanpol, B. (2001). Approaches to Multicultural Education in Preservice Teacher Education: Philosophical Frameworks and Models or Teaching. The Urban Review, 33, 87-105. https://doi.org/10.1023/A:1010389023211

Kardeş, S., \& Akman, B. (2018). Suriyeli sığınmacıların eğitimine yönelik öğretmen görüşleri. İlköğretim Online, 17(3), 1224-1237. https://doi.org/10.17051/ilkonline.2018.466333

Konda. (2011). Kurt Meselesi'nde Algl ve Beklentiler. İstanbul: İletişim Yayınları.

Leistyna, P. (2002). Defining and Designing Multiculturalism: One School System's Efforts. State University of New York Press, SUNY series.

Levent, F., \& Cayak, S. (2017). School Administrators' Views on Syrian Students' Education in Turkey. Hasan 
Ali Yucel Egitim Fakultesi Dergisi, 14(1), 21.

Manap-Kırmızıgül, C. (2017). Türkiye'deki Mültecilerin Dezavantajlılı̆̆ı. Toplum Ve Demokrasi Dergisi, 11(24).

McLaren, P. (2003). Life in schools: An introduction to critical pedagogy in the foundations of Education (4th ed.). Albany, NY: Allyn and Bacon.

McLaren, P. L. (1995). Multicultural education, critical pedagogy, and the politics of difference In C.E. Sleeter \& P. L. McLaren (Eds.), White terror and oppositional agency: Towards critical multiculturalism (pp. 33-70). Albany, NY: State. University of New York Press.

Mercan-Uzun, E., \& Butun, E. (2016). Okul Öncesi Eğitim Kurumlarındaki Suriyeli Slğınmacı Çocukların Karşılaş̧tıları Sorunlar Hakkında Öğretmen Görüşleri. Uluslararası Erken Çocukluk Eğitimi Çalışmaları Dergisi, Hasan Kalyoncu Üniversitesi.

Millar, J. (2004). Systematic Reviews for Policy Analysis. In S. Becker and A. Byrman (Eds.), Understanding Research for Social Policy and Practice: Themes, Methods and Approaches. Bristol: Policy Press.

Milner, J., \& Loescher. G. (2011). Refugee Studies. Centre Oxford Department of the International Development University of Oxford.

MoNE, Ministry of National Education. (2016). Suriyeli Çocukların Türk Eğitim Sistemine Entegrasyonunun Desteklenmesi Projesi PICTES.

MoNE, Ministry of National Education. (2017). Öğretmen Strateji Belgesi: 2017-2023. Öğretmen Yetiştirme ve Geliştirme Genel Müdürlüğü, Ankara

MoNE, Ministry of National Education. (2018). Geçici koruma altındaki öğrencilerin eğitim hizmetleri. Retrieved from https://hbogm.meb.gov.tr/meb_iys_dosyalar/2018_03/05103521_05-03-2018_Ynternet_BYlteni.pdf

Mthethwa-Sommers, S. (2014). Narratives of Social Justice Educators. Standing Firm Springer. Cham. https://doi.org/10.1007/978-3-319-08431-2

Nieto, S. (1994). Affirmation, solidarity, and critique: Moving beyond tolerance in multicultural education. Multicultural Education, 1(3), 9-12, 35-39. Retrieved from http://www.sonianieto.com/OLD/PDF/Moving\%20beyond\%20tolerance\%20Mult\%20Ed\%201994.pdf

Nieto, S. (2017). Language, Culture, and Teaching: Critical Perspectives (3rd ed.). Routledge. https://doi.org/10.4324/9781315465692

Nieto, S., \& Bode, P. (2008). Affirming diversity: The sociopolitical context of multicultural education (5th ed.). Boston: Pearson.

Özer, Y., Komşuoğlu, A., \& Ateşok, Z. (2016). Türkiye'deki Suriyeli Çocukların Eğitimi: Sorunlar ve Çözüm Önerileri. The Journal of Academic Social Science, 4(37), 76-110. https://doi.org/10.16992/ASOS.11696

Sleeter, C. E. (2018). Multicultural Education Past, Present, and Future: Struggles for Dialog and Power-Sharing. International Journal of Multicultural Education, 20(1), 5-20. https://doi.org/10.18251/ijme.v20i1.1663

Sleeter, C. E., \& Grant, C. (1987). An Analysis of Multicultural Education in the United States. Harvard Educational Review, 57(4). https://doi.org/10.17763/haer.57.4.v810xr0v3224×316

Solomon, R. P. (1996). Beyond celebratory multiculturalism: Where Teachers fear to tread. In K. A. McLeod (Ed.), Multicultural education: The state of the art national study, report \#4 (pp. 67-74). Winnipeg, MB: CASLT.

Taştan, C., \& Çelik, Z. (2017). Education of Syrian children in Turkey: Challenges and Recommendations. Eğitim-Bir-Sen Stratejik Araştırmalar Merkezi, Educators Trade Union Research Center.

Ukpokodu, O. N. (2008). Teachers reflections on pedagogies that enhance learning in an online course on teaching for equity and social justice. Journal of Interactive Online Learning, 7, 227-255. Retrieved from http://www.ncolr.org/jiol/issues/pdf/7.3.5.pdf

United Nations High Commissioner for Refugees (UNHCR). (2017). Global Trends. Forced Displacement in 2017.

Vavrus, M. (2002). Transforming the Multicultural Education of Teachers: Theory, Research, and Practice. New York: Teachers College Press.

Villegas, A. M., \& Lucas, T. (2002). Preparing Culturally Responsive Teachers: Rethinking the Curriculum 
Journal of Teacher Education, 53(20). https://doi.org/10.1177/0022487102053001003

Zeichner, K. M., \& Hoeft, K. (1996). Handbook of research on teacher Education (2nd ed). In J. Sikula, T. Buttery \& E. Guyto (Eds.), Teacher socialization for cultural diversity (pp. 525-547). New York: Macmillan.

\section{Appendix A}

\begin{tabular}{|c|c|c|}
\hline Author(s) & Year & Article \\
\hline Sleeter, Christine E. & 2018 & $\begin{array}{l}\text { Multicultural Education Past, Present, and Future: Struggles for Dialog and } \\
\text { Power-Sharing. International Journal of Multicultural Education, [S.1.], v. 20, n. 1, pp. 5- } \\
\text { 20, feb. } 2018\end{array}$ \\
\hline $\begin{array}{l}\text { Gutentag, T., Horenczyk, } \\
\text { G., \& Tatar, M. }\end{array}$ & 2018 & $\begin{array}{l}\text { Teachers' Approaches Toward Cultural Diversity Predict Diversity-Related Burnout and } \\
\text { Self-Efficacy. Journal of Teacher Education, 69(4), 408-419. }\end{array}$ \\
\hline Sleeter, C. E. & 2017 & $\begin{array}{l}\text { Critical Race Theory and the Whiteness of Teacher Education. Urban Education, 52(2), } \\
155-169\end{array}$ \\
\hline Wayne Journell & 2017 & $\begin{array}{l}\text { Politically Conservative Preservice Teachers and the Spiral of Silence: Implications for } \\
\text { Teacher Education. Teacher Education Quarterly, Vol. 44, No. } 2 \text { (Spring 2017), pp. 105- } \\
129\end{array}$ \\
\hline Berchini, C. N & 2017 & $\begin{array}{l}\text { Critiquing Un/Critical Pedagogies to Move Toward a Pedagogy of Responsibility in } \\
\text { Teacher Education. Journal of Teacher Education, 68(5), 463-475. }\end{array}$ \\
\hline Thompson, Franklin Titus & & $\begin{array}{l}\text { "Advancing the Dialogue on Multicultural Instructional Approaches," Journal of } \\
\text { Curriculum, Teaching, Learning and Leadership in Education: Vol. 2: Iss. 1, Article } 7 .\end{array}$ \\
\hline $\begin{array}{l}\text { Howlett, K., M.; Bowles, } \\
\text { F., A.; Lincoln, F. }\end{array}$ & 2017 & $\begin{array}{l}\text { Infusing Multicultural Literature into Teacher Education Programs: Three Instructional } \\
\text { Approaches Multicultural Education, v24, n3-4, p10-15, Spr-Sum } 2017\end{array}$ \\
\hline Lucey, T., A.; White, E., S. & 2017 & $\begin{array}{l}\text { Mentorship in Higher Education: Compassionate Approaches Supporting Culturally } \\
\text { Responsive Pedagogy Multicultural Education, v24, n2, p11-17, Win }\end{array}$ \\
\hline Christopher C. Martell & 2017 & $\begin{array}{l}\text { Approaches to teaching race in elementary social studies: A case study of preservice } \\
\text { teachers The Journal of Social Studies Research Volume 41, Issue 1, January 2017, Pages } \\
75-87\end{array}$ \\
\hline $\begin{array}{l}\text { Clark, C., Sapon-Shevin, } \\
\text { M., Brimhall -Vargas, M., } \\
\text { McGhie, T., \& Nieto, S. }\end{array}$ & 2017 & $\begin{array}{l}\text { Critical Multicultural Education as an Analytical Point of Entry into Discussion of } \\
\text { Intersectional Scholarship: A Focus on Race, as Well as Class, Gender, Sexuality, } \\
\text { Dis/Ability, and Family Configuration. Taboo: The Journal of Culture and Education, } 16 \\
\text { (1). }\end{array}$ \\
\hline CHO, Hyunhee. & 2017. & $\begin{array}{l}\text { Navigating the Meanings of Social Justice, Teaching for Social Justice, and Multicultural } \\
\text { Education. International Journal of Multicultural Education, [S.1.], v. 19, n. 2, pp. 1-19, } \\
\text { June }\end{array}$ \\
\hline $\begin{array}{l}\text { Hall, G. C. N., Yip, T., \& } \\
\text { Zárate, M. A. }\end{array}$ & 2016 & $\begin{array}{l}\text { On becoming multicultural in a monocultural research world: A conceptual approach to } \\
\text { studying ethnocultural diversity. American Psychologist, } 71(1), 40-51 \text {. }\end{array}$ \\
\hline $\begin{array}{l}\text { Tichnor-Wagner, A, } \\
\text { Parkhouse, H., Glazier, } \\
\text { J.\& Cain, J }\end{array}$ & 2016 & $\begin{array}{l}\text { Expanding approaches to teaching for diversity and social justice in K-12 education: } \\
\text { Fostering global citizenship across the content areas. education policy analysis archives, } \\
24,59 \text {. }\end{array}$ \\
\hline Alismail, Halah Ahmed & 2016 & $\begin{array}{l}\text { Multicultural Education: Teachers' Perceptions and Preparation } \\
\text { Journal of Education and Practice, v7, n11, pp. 139-146, } 201\end{array}$ \\
\hline $\begin{array}{l}\text { Agirdag, O., Merry, M. S., } \\
\text { \& Van Houtte, M. }\end{array}$ & 2016 & $\begin{array}{l}\text { Teachers' Understanding of Multicultural Education and the Correlates of Multicultural } \\
\text { Content Integration in Flanders. Education and Urban Society, 48(6), 556-582. }\end{array}$ \\
\hline Paul C. Gorski & 2016 & $\begin{array}{l}\text { Making better multicultural and social justice teacher educators: a qualitative analysis of } \\
\text { the professional learning and support needs of multicultural teacher education faculty, } \\
\text { Multicultural Education Review, } 8(3), 139-159 \text {, }\end{array}$ \\
\hline $\begin{array}{l}\text { Ramona F. Amthor \& } \\
\text { Kevin Roxas }\end{array}$ & 2016 & $\begin{array}{l}\text { Multicultural Education and Newcomer Youth: Re-Imagining a More Inclusive Vision } \\
\text { for Immigrant and Refugee Students, Educational Studies, 52(2), 155-176 }\end{array}$ \\
\hline $\begin{array}{l}\text { Logvinova O., K. } \\
\text { \&Ivanova G., P. }\end{array}$ & 2016 & $\begin{array}{l}\text { Pre-Service Teacher Multicultural Education in Russia: Problems and Responses Indian } \\
\text { Journal of Science and Technology, Vol 9(29) }\end{array}$ \\
\hline $\begin{array}{l}\text { Martin, Renee J.; } \\
\text { Dagostino-Kalniz, Victoria }\end{array}$ & 2015 & $\begin{array}{l}\text { Living Outside Their Heads: Assessing the Efficacy of a Multicultural Course on the } \\
\text { Attitudes of Graduate Students in Teacher Education. Journal of Cultural Diversity. } \\
\text { Summer2015, Vol. } 22 \text { Issue 2, pp. 43-49. } 7 \text { p }\end{array}$ \\
\hline $\begin{array}{l}\text { Zeichner K., Payne, K., A. } \\
\text { \& Brayko, K. }\end{array}$ & 2015 & $\begin{array}{l}\text { Democratizing Teacher Education Journal of Teacher Education } \\
\text { 2015, Vol. 66(2), 122-135 }\end{array}$ \\
\hline Nieto, S. & 2015 & $\begin{array}{l}\text { Moving beyond Tolerance in Multicultural Education. Multicultural Education, v1 n4 pp } \\
\text { 9-12, 35-38 Spr } 1994\end{array}$ \\
\hline Santamaría, L. J & 2014. & Critical Change for the Greater Good: Multicultural Perceptions in Educational \\
\hline
\end{tabular}




\begin{tabular}{|c|c|c|}
\hline & & $\begin{array}{l}\text { Leadership Toward Social Justice and Equity. Educational Administration Quarterly, 50(3), } \\
\text { 347-391. }\end{array}$ \\
\hline Thompson, F. T. & 2014. & $\begin{array}{l}\text { Effective Multicultural Instruction: A Non-Color-Blind Perspective. SAGE Open. Journal } \\
\text { of Education and Practice Vol.7, No.11, } 2016\end{array}$ \\
\hline $\begin{array}{l}\text { Desmond S. King and } \\
\text { Rogers M. Smith, }\end{array}$ & 2014 & $\begin{array}{l}\text { Multicultural Education: Teachers' Perceptions and Preparation "Without Regard to } \\
\text { Race": Critical Ideational Development in Modern American Politics, The Journal of } \\
\text { Politics 76, no. } 4 \text { (October 2014), 958-971. }\end{array}$ \\
\hline Daniela Martin & 2014 & $\begin{array}{l}\text { Good education for all? Student race and identity development in the multicultural } \\
\text { classroom International Journal of Intercultural Relations, Volume } 39,2014 \text {, pp. 110-123 }\end{array}$ \\
\hline $\begin{array}{l}\text { Ndemanu, Michael } \\
\text { Takafor }\end{array}$ & 2014 & $\begin{array}{l}\text { Multicultural Teacher Education Courses Are Not Designed for All Pre-service } \\
\text { Teachers: An African American Student Teacher's Perspective. } \\
\text { Journal of Instructional Psychology. 2014, Vol. } 41 \text { Issue 1-4, pp. 64-78. 15p. }\end{array}$ \\
\hline Lorri J. Santamaría & 2014 & $\begin{array}{l}\text { Critical Change for the Greater Good: Multicultural Perceptions in Educational } \\
\text { Leadership Toward Social Justice and Equity. Educational Administration Quarterly, 50(3), } \\
347-391 \text {. }\end{array}$ \\
\hline $\begin{array}{l}\text { Ilana Paul-Binyamin, Roni } \\
\text { Reingold }\end{array}$ & 2014 & $\begin{array}{l}\text { Multiculturalism in teacher education institutes - The relationship between formulated } \\
\text { official policies and grassroots initiatives } \\
\text { Teaching and Teacher Education, Volume 42, 2014, pp. } 47-57\end{array}$ \\
\hline $\begin{array}{l}\text { Ritchie, S.; S., An,; } \\
\text { Cone, ; Bullock, P. }\end{array}$ & 2013 & $\begin{array}{l}\text { Teacher Education for Social Change: Transforming a Content Methods Course Block } \\
\text { Current Issues in Comparative Education, v15, n2, pp. 63-83, Spr }\end{array}$ \\
\hline Robinson, Jasmine & 2013 & Critical Approaches to Multicultural Children's Literature in the Elementary Classroom: \\
\hline Angela. & & $\begin{array}{l}\text { Challenging Pedagogies of Silence New England Reading Association Journal; Portland } \\
\text { Vol. 48, Iss. 2, (2013), 43-51,88. }\end{array}$ \\
\hline Smith, Patriann. & 2013 & $\begin{array}{l}\text { Accomplishing The Goals of Multicultural Educatıon. Curriculum \& Teaching Dialogue. } \\
\text { 2013, Vol. } 15 \text { Issue 1/2, pp. 27-40. 14p. }\end{array}$ \\
\hline Krummel, A. & 2013 & $\begin{array}{l}\text { Multicultural Teaching Models to Educate Pre-Service Teachers: Reflections, } \\
\text { Service-Learning, and Mentoring. Current Issues in Education, 16(1). }\end{array}$ \\
\hline $\begin{array}{l}\text { Carl A. Grant \& Sejung } \\
\text { Ham }\end{array}$ & 2013 & $\begin{array}{l}\text { Multicultural Education Policy in South Korea: Current Struggles and Hopeful Vision, } \\
\text { Multicultural Education Review, 5(1), 67-95. }\end{array}$ \\
\hline $\begin{array}{l}\text { Paul C. Gorski, Shannon } \\
\text { N. Davis \& Abigail Reiter }\end{array}$ & 2013 & $\begin{array}{l}\text { An Examination of the (In)visibility of Sexual Orientation, Heterosexism, Homophobia, } \\
\text { and Other LGBTQ Concerns in U.S. Multicultural Teacher Education Coursework, } \\
\text { Journal of LGBT Youth, 10(3), 224-248 }\end{array}$ \\
\hline $\begin{array}{l}\text { Ndura, E., \& Dogbevia } \\
\text { M., K. }\end{array}$ & 2013 & $\begin{array}{l}\text { Re-envisioning Multicultural Education in Diverse Academic Contexts. Procedia - Social } \\
\text { and Behavioral Sciences, Volume 93, 2013, pp. 1015-1019 }\end{array}$ \\
\hline Paul C. Gorski & 2012 & $\begin{array}{l}\text { Instructional, Institutional, And Sociopolitical Challenges of Teaching. Multicultural } \\
\text { Teacher Education Courses the Teacher Educator, 47, 216-235 }\end{array}$ \\
\hline $\begin{array}{l}\text { Paul C. Gorski, Shannon } \\
\text { N. Davis \& Abigail Reiter }\end{array}$ & 2012 & $\begin{array}{l}\text { Self-Efficacy and Multicultural Teacher Education in the United States: The Factors That } \\
\text { Influence Who Feels Qualified to be a Multicultural Teacher Educator, Multicultural } \\
\text { Perspectives, 14(4), 220-228, }\end{array}$ \\
\hline Lerner, Amy B. & 2012 & $\begin{array}{l}\text { The Educational Resettlement of Refugee Children: Examining Several Theoretical } \\
\text { Approaches Multicultural Education, v20, n1, pp. 9-14, Fall } 2012\end{array}$ \\
\hline Dervin, Fred et al & 2012 & $\begin{array}{l}\text { Multicultural Education in Finland: Renewed Intercultural Competences to the Rescue? } \\
\text { International Journal of Multicultural Education, [S.1.], v. 14, n. 3, dec. } 2012\end{array}$ \\
\hline $\begin{array}{l}\text { Yang, Y., \& Montgomery, } \\
\text { D. }\end{array}$ & 2011 & $\begin{array}{l}\text { Behind Cultural Competence: The Role of Causal Attribution in Multicultural Teacher. } \\
\text { Education. Australian Journal of Teacher Education, 36(9). }\end{array}$ \\
\hline $\begin{array}{l}\text { Karuppiah N., \& } \\
\text { Berthelsen D. }\end{array}$ & 2011 & $\begin{array}{l}\text { Multicultural Education: The Understandings of Preschool Teachers in Singapore Volume: } \\
36 \text { issue: } 4 \text {, pp. } 38-42\end{array}$ \\
\hline $\begin{array}{l}\text { Gorski, P. C., \& Goodman, } \\
\text { R. D. }\end{array}$ & 2011 & $\begin{array}{l}\text { Is There a "Hierarchy of Oppression" in U.S. Multicultural Teacher Education } \\
\text { Coursework? Action in Teacher Education, 33(5-6), 455-475 }\end{array}$ \\
\hline $\begin{array}{l}\text { Xenia Meyer, Barbara A. } \\
\text { Crawford }\end{array}$ & 2011 & $\begin{array}{l}\text { Teaching science as a cultural way of knowing: merging authentic inquiry, nature of } \\
\text { science, and multicultural strategies Cultural Studies of Science Education, 2011, Volume } \\
6 \text {, Number 3, Page } 525\end{array}$ \\
\hline Dilys Schoorman & 2011 & $\begin{array}{l}\text { Reconceptualizing Teacher Education as a Social Justice Undertaking: Underscoring the } \\
\text { Urgency for Critical Multiculturalism in Early Childhood Education, Childhood } \\
\text { Education, 87(5), 341-344, }\end{array}$ \\
\hline $\begin{array}{l}\text { Dedeoglu, H., \& Lamme, } \\
\text { L. L. }\end{array}$ & 2011 & $\begin{array}{l}\text { Selected Demographics, Attitudes, and Beliefs About Diversity of Preservice Teachers. } \\
\text { Education and Urban Society, 43(4), 468-485 }\end{array}$ \\
\hline Pickett, A., \& York, J. G. & 2011 & $\begin{array}{l}\text { Multicultural teacher education: Developing a hermeneutic disposition. Philosophy of } \\
\text { Education Archive, } 68-77 \text {. }\end{array}$ \\
\hline $\begin{array}{l}\text { Mayo, Sandra; Larke, } \\
\text { Patricia J. }\end{array}$ & 2011 & $\begin{array}{l}\text { Multicultural Education Transformation in Higher Education: Getting Faculty to "Buy } \\
\text { In" Journal of Case Studies in Education, v1 Jan } 2011\end{array}$ \\
\hline
\end{tabular}




\begin{tabular}{|c|c|c|}
\hline Ozturgut, O. & 2011 & Understanding Multicultural Education. Current Issues in Education, 14(2). \\
\hline $\begin{array}{l}\text { Laura B. Perry \& Leonie } \\
\text { Southwell }\end{array}$ & 2011 & $\begin{array}{l}\text { Developing intercultural understanding and skills: models and approaches, Intercultural } \\
\text { Education, 22(6), 453-466, }\end{array}$ \\
\hline $\begin{array}{l}\text { Theresa Alviar-Martin, } \\
\text { Li-Ching Ho }\end{array}$ & 2011 & $\begin{array}{l}\text { "So, where do they fit in?" Teachers' perspectives of multi-cultural education and } \\
\text { diversity in Singapore Teaching and Teacher Education, Volume 27, Issue 1, 2011, pp. } \\
\text { 127-135 }\end{array}$ \\
\hline Syed, K. T. & 2010 & $\begin{array}{l}\text { Canadian Educators' Narratives of Teaching Multicultural Education. International Journal } \\
\text { of Canadian Studies, (42), 255-269. }\end{array}$ \\
\hline $\begin{array}{l}\text { Lori Czop Assaf, Rubén } \\
\text { Garza and Jennifer Battle }\end{array}$ & 2010 & $\begin{array}{l}\text { Multicultural Teacher Education: Examining the Perceptions, Practices, and Coherence } \\
\text { in One Teacher Preparation Program, Teacher Education Quarterly, Vol. 37, No. 2, Shaping } \\
\text { New Models of Teacher Education (Spring 2010), pp. 115-135 }\end{array}$ \\
\hline Ken Zeichner & 2010 & $\begin{array}{l}\text { Competition, economic rationalization, increased surveillance, and attacks on diversity: } \\
\text { Neo-liberalism and the transformation of teacher education in the U.S Teaching and } \\
\text { Teacher Education Volume 26, Issue 8, November 2010, Pages 1544-1552 }\end{array}$ \\
\hline GORSKI, Paul Cameron & 2010 & $\begin{array}{l}\text { The Scholarship Informing the Practice: Multicultural Teacher Education Philosophy } \\
\text { and Practice in the U.S. International Journal of Multicultural Education, [S.1.], v. 12, n. 2, } \\
\text { nov. } 2010\end{array}$ \\
\hline $\begin{array}{l}\text { Dilys Schoorman, Ira } \\
\text { Bogotch }\end{array}$ & 2010 & $\begin{array}{l}\text { Conceptualizations of multicultural education among teachers: Implications for practice } \\
\text { in universities and schools, Teaching and Teacher Education, 26, 1041-1048 }\end{array}$ \\
\hline $\begin{array}{l}\text { Michalinos Zembylas \& } \\
\text { Sotiroula Iasonos }\end{array}$ & 2010 & $\begin{array}{l}\text { Leadership styles and multicultural education approaches: an exploration of their } \\
\text { relationship, International Journal of Leadership in Education, 13(2), 163-183 }\end{array}$ \\
\hline Keengwe, J. & 2010 & $\begin{array}{l}\text { Fostering Cross-Cultural Competence in Preservice Teachers Through Multicultural } \\
\text { Education Experiences, Early Childhood Educ J (2010), 38, } 197 .\end{array}$ \\
\hline L Rosenthal, SR Levy & 2010 & $\begin{array}{l}\text { The colorblind, multicultural, and polycultural ideological approaches to improving } \\
\text { intergroup attitudes and relations. Social Issues and Policy Review, } 2010 \text { - Wiley Online } \\
\text { Library }\end{array}$ \\
\hline $\begin{array}{l}\text { Camp, Emilie M.; } \\
\text { Oesterreich, Heather A. }\end{array}$ & 2010 & $\begin{array}{l}\text { Uncommon Teaching in Commonsense Times: A Case Study of a Critical Multicultural } \\
\text { Educator and the Academic Success of Diverse Student Populations. Multicultural } \\
\text { Education, v17 n2 p20-26 Win } 2010\end{array}$ \\
\hline Melissa L. Gibson & 2010 & $\begin{array}{l}\text { Are We "Reading the World"? A Review of Multicultural Literature on Globalization, } \\
\text { Multicultural Perspectives, 12(3), 129-137 }\end{array}$ \\
\hline Ngo, B & 2010 & $\begin{array}{l}\text { Doing "Diversity" at Dynamic High: Problems and Possibilities of Multicultural } \\
\text { Education in Practice. Education and Urban Society, 42(4), 473-495 }\end{array}$ \\
\hline Owen, PamelaM. & 2010 & $\begin{array}{l}\text { Increasing Preservice Teachers' Support for Multicultural Education. Multicultural } \\
\text { Perspectives. Jan-Mar 2010, Vol. 12, Issue 1, pp. 18-25. 8p. }\end{array}$ \\
\hline Paul C. Gorski & 2010 & $\begin{array}{l}\text { The Scholarship Informing the Practice: Multicultural Teacher Education Philosophy } \\
\text { and Practice in the United States International Journal of Multicultural Education } 2010 \text { Vol. } \\
\text { 12, No. } 2\end{array}$ \\
\hline $\begin{array}{l}\text { Blincoe, S., \& Harris, M. } \\
\text { J. }\end{array}$ & 2009. & $\begin{array}{l}\text { Prejudice reduction in white students: Comparing three conceptual approaches. Journal } \\
\text { of Diversity in Higher Education, 2(4), 232-242. }\end{array}$ \\
\hline Lowenstein, K. L. & 2009. & $\begin{array}{l}\text { The Work of Multicultural Teacher Education: Reconceptualizing White Teacher } \\
\text { Candidates as Learners. Review of Educational Research, 79(1), 163-196. }\end{array}$ \\
\hline Paul C. Gorski & 2009 & $\begin{array}{l}\text { What we're teaching teachers: An analysis of multicultural teacher education } \\
\text { coursework syllabi. Teaching and Teacher Education Volume 25, Issue 2, February 2009, } \\
\text { Pages 309-318 }\end{array}$ \\
\hline Smith, Earl Bradford & 2009 & $\begin{array}{l}\text { Approaches to Multicultural Education in Preservice Teacher Education: Philosophical } \\
\text { Frameworks and Models for Teaching, Multicultural Education, v16, n3, pp. 45-50, Spr } \\
2009\end{array}$ \\
\hline $\begin{array}{l}\text { Wang, J.-C., \& } \\
\text { Humphreys, J. T. }\end{array}$ & 2009. & $\begin{array}{l}\text { Multicultural and popular music content in an American music teacher education } \\
\text { program. International Journal of Music Education, 27(1), 19-36. }\end{array}$ \\
\hline Gorski, P. C. & 2009. & $\begin{array}{l}\text { Insisting on Digital Equity: Reframing the Dominant Discourse on Multicultural } \\
\text { Education and Technology. Urban Education, } 44(3), 348-364 \text {. }\end{array}$ \\
\hline Luther, Kristin. & 2009 & $\begin{array}{l}\text { Celebration and Separation: A Troublesome Approach to Multicultural Education. } \\
\text { Multicultural Perspectives. Oct-Dec2009, Vol. } 11 \text { Issue 4, pp. 211-216. 6p. } 1\end{array}$ \\
\hline Michael Vavrus & 2009 & $\begin{array}{l}\text { Sexuality, schooling, and teacher identity formation: A critical pedagogy for teacher } \\
\text { education Teaching and Teacher Education } 25 \text { (2009), 383-390 }\end{array}$ \\
\hline Julia Resnik & 2009 & $\begin{array}{l}\text { Multicultural Education - Good for Business But Not for The State? The Ib Curriculum } \\
\text { And Global Capitalısm, British Journal of Educational Studies, 57(3), 217-244 }\end{array}$ \\
\hline $\begin{array}{l}\text { Kumagai, A. K. \& Lypson, } \\
\text { M. L. }\end{array}$ & 2009. & $\begin{array}{l}\text { Beyond Cultural Competence: Critical Consciousness, Social Justice, and Multicultural } \\
\text { Education. Academic Medicine, } 84(6), 782-787\end{array}$ \\
\hline Paul C. Gorski & 2009 & What we're teaching teachers: An analysis of multicultural teacher education coursework \\
\hline
\end{tabular}




\begin{tabular}{|c|c|c|}
\hline & & $\begin{array}{l}\text { syllabi Teaching and Teacher Education Volume 25, Issue 2, February 2009, Pages 309- } \\
318\end{array}$ \\
\hline Rogers-Sirin, L. & 2008 & $\begin{array}{l}\text { Approaches to multicultural training for professionals: A guide for choosing an } \\
\text { appropriate program. Professional Psychology: Research and Practice, 39(3), 313-319. }\end{array}$ \\
\hline Neil O. Houser & 2008 & $\begin{array}{l}\text { Cultural plunge: a critical approach for multicultural development in teacher education, } \\
\text { Race Ethnicity and Education, } 11(4), 465-482 \text {, }\end{array}$ \\
\hline Hanna Kaisa Nordström & 2008 & Environmental Education and Multicultural Education - Too Close to Be Separate? \\
\hline & & International Research in Geographical and Environmental Education, 17(2), 131-145, \\
\hline $\begin{array}{l}\text { Michalinos Zembylas \& } \\
\text { Sotiroula Iasonos }\end{array}$ & 2008 & $\begin{array}{l}\text { Leadership styles and multicultural education approaches: an exploration of their } \\
\text { relationship, International Journal of Leadership in Education, 13(2), 163-183 }\end{array}$ \\
\hline Asher, $\mathrm{N}$ & 2007 & $\begin{array}{l}\text { Made in the (Multicultural) U.S.A.: Unpacking Tensions of Race, Culture, Gender, and } \\
\text { Sexuality in Education. Educational Researcher, 36(2), 65-73. }\end{array}$ \\
\hline $\begin{array}{l}\text { Katherine Richardson } \\
\text { Bruna }\end{array}$ & 2007 & $\begin{array}{l}\text { Finding new words: how I use critical literacy in my multicultural teacher education } \\
\text { classroom, Journal of Education for Teaching, 33(1), 115-118, }\end{array}$ \\
\hline $\begin{array}{l}\text { Laura S. Abrams \& } \\
\text { Priscilla Gibson }\end{array}$ & 2007 & $\begin{array}{l}\text { Teachıng Notes: Reframıng Multıcultural Educatıon: Teachıng White Privilege in the } \\
\text { Social Work Curriculum, Journal of Social Work Education, 43(1), 147-160 }\end{array}$ \\
\hline Abril, C. R. & 2006 & $\begin{array}{l}\text { Learning outcomes of two approaches to multicultural music education. International } \\
\text { Journal of Music Education, 24(1), 30-42. }\end{array}$ \\
\hline Paul C. Gorski & 2006 & $\begin{array}{l}\text { Complicity with conservatism: the de-politicizing of multicultural and intercultural } \\
\text { education Intercultural Education, Vol. 17, No. 2, May 2006, pp. 163-177 }\end{array}$ \\
\hline Elizabeth BifuhAmbe & 2006 & $\begin{array}{l}\text { Fostering multicultural appreciation in pre-service teachers through multicultural } \\
\text { curricular transformation, Teaching and Teacher Education, Volume 22, Issue 6, August } \\
\text { 2006, Pages } 690-699\end{array}$ \\
\hline Cho, G. \& & 2005 & Is Ignorance Bliss? Pre-service Teachers' Attitudes Toward Multicultural Education. The \\
\hline DeCastro-Ambrosetti, D. & & $\begin{array}{l}\text { High School Journal, } 89(2), 24-28 . \text { The University of North Carolina Press. Retrieved } \\
\text { April 16, 2019, from Project MUSE database. }\end{array}$ \\
\hline Gay, G. & 2005 & $\begin{array}{l}\text { Politics of Multicultural Teacher Education. Journal of Teacher Education, 56(3), 221- } \\
228 .\end{array}$ \\
\hline H. Richard Milner & 2005 & $\begin{array}{l}\text { Developing a Multicultural Curriculum in a Predominantly White Teaching Context: } \\
\text { Lessons from an African American Teacher in a Suburban English Classroom, Curriculum } \\
\text { Inquiry, 35(4), 391-427 }\end{array}$ \\
\hline Pewewardy, Cornel & 2005 & $\begin{array}{l}\text { Shared Journaling: A Methodology for Engaging White Preservice Students into } \\
\text { Multicultural Education Discourse Teacher Education Quarterly, v32, n1, pp. 41-60, Win } \\
2005\end{array}$ \\
\hline $\begin{array}{l}\text { Honigsfeld, A., \& } \\
\text { MarjorieSchiering }\end{array}$ & 2004 & $\begin{array}{l}\text { Diverse Approaches to the Diversity of Learning Styles in Teacher Education, Educational } \\
\text { Psychology, 24(4), 487-507 }\end{array}$ \\
\hline Wasonga, T. A., \& Joyce & 2004 & Diversity and the Modeling of Multicultural Principles of Education in a Teacher \\
\hline A. Piveral & & Education Program, Multicultural Perspectives, 6(3), 42-47 \\
\hline Carmen Montecinos & 2004 & $\begin{array}{l}\text { Paradoxes in multicultural teacher education research: students of color positioned as } \\
\text { objects while ignored as subjects, International Journal of Qualitative Studies in Education, } \\
17(2), 167-181 \text {, }\end{array}$ \\
\hline $\begin{array}{l}\text { Trent, S. C., \& Dixon, D. } \\
\text { J. }\end{array}$ & 2004 & $\begin{array}{l}\text { "My Eyes Were Opened": Tracing the Conceptual Change of Pre-Service Teachers in a } \\
\text { Special Education/Multicultural Education Course. Teacher Education and Special } \\
\text { Education, 27(2), 119-133. }\end{array}$ \\
\hline $\begin{array}{l}\text { Horton, Julie; Scott, } \\
\text { Dominic }\end{array}$ & 2004 & $\begin{array}{l}\text { White Students' Voices in Multicultural Teacher Education Preparation Multicultural } \\
\text { Education, v11, n4, pp. 12-16, Sum } 2004\end{array}$ \\
\hline Cochran-Smith, Marilyn & 2003 & $\begin{array}{l}\text { The Multiple Meanings of Multicultural Teacher Education: A Conceptual Framework, } \\
\text { Teacher Education Quarterly, v30, n2, pp. 7-26 }\end{array}$ \\
\hline Helfenbein, Jr., Robert J & 2003 & $\begin{array}{l}\text { Troubling Multiculturalism: The New Work Order, Anti Anti-Essentialism, and a Cultural } \\
\text { Studies Approach to Education. Multicultural Perspectives. 2003, Vol. 5, Issue 4, pp. 10- } \\
\text { 16. } 7 \text { p. }\end{array}$ \\
\hline Hudson, A. H. & 2003 & $\begin{array}{l}\text { Multicultural Education and the Postcolonial Turn. Policy Futures in Education, 1(2), } \\
381-401 .\end{array}$ \\
\hline $\begin{array}{l}\text { Allison } \\
\text { Cumming-McCann }\end{array}$ & 2003 & $\begin{array}{l}\text { Multicultural Education Connecting Theory to Practice, Focus on Basics National Center } \\
\text { for the Study of Adult Learning and Literacy (NCSALL), Volume 6, Issue B, February } \\
2003\end{array}$ \\
\hline Michelle Jay & 2003 & $\begin{array}{l}\text { Critical Race Theory, Multicultural Education, and the Hidden Curriculum of Hegemony, } \\
\text { Multicultural Perspectives, 5(4), 3-9, }\end{array}$ \\
\hline $\begin{array}{l}\text { Martin, R. J., \& Van } \\
\text { Gunten, D. M. }\end{array}$ & 2002 & $\begin{array}{l}\text { Reflected Identities: Applying Positionality and Multicultural Social Reconstructionism in } \\
\text { Teacher Education. Journal of Teacher Education, 53(1), 44-54. }\end{array}$ \\
\hline Jennings, L. B., \& Smith, & 2002 & Examining the role of critical inquiry for transformative practices: Two joint case studies \\
\hline
\end{tabular}




\begin{tabular}{|c|c|c|}
\hline C. $P$. & & of multicultural teacher education. Teachers College Record, 104(3), 456-481. \\
\hline Lee Anne Bell & 2002 & Sincere Fictions: The Pedagogical Challenges of Preparing White Teachers for \\
\hline Bennett, C. & 2001 & $\begin{array}{l}\text { Multicultural Classrooms, Equity \& Excellence in Education, 35(3), 236-244, } \\
\text { Genres of Research in Multicultural Education. Review of Educational Research, 71(2), } \\
171-217 .\end{array}$ \\
\hline $\begin{array}{l}\text { Jenks, C., Lee, J.O. \& } \\
\text { Kanpol, B. }\end{array}$ & 2001 & $\begin{array}{l}\text { Approaches to Multicultural Education in Preservice Teacher Education: Philosophical } \\
\text { Frameworks and Models for TeachingThe Urban Review 33(87). }\end{array}$ \\
\hline Gaudelli, William. & 2001 & $\begin{array}{l}\text { Reflections on multicultural education: A teacher's experience } \\
\text { Multicultural Education; San Francisco Vol. 8, Iss. 4, (Summer 2001): 35-37. }\end{array}$ \\
\hline Nieto, $\mathrm{S}$. & 2000 & $\begin{array}{l}\text { Placing equity front and center: Some thoughts on transforming teacher education for a } \\
\text { new century. Journal of Teacher Education, } 51 \text { (3), 180-187. }\end{array}$ \\
\hline Roux, Johann Le. & 2000 & $\begin{array}{l}\text { Multicultural education: a new approach for a new South African dispensation. Academic } \\
\text { Journal of Intercultural Education. Apr 2000, Vol. 11, Issue 1, pp. 19-29. 11p. }\end{array}$ \\
\hline Olneck, M & 2000 & $\begin{array}{l}\text { Can Multicultural Education Change What Counts as Cultural Capital? American } \\
\text { Educational Research Journal, 37(2), 317-348. }\end{array}$ \\
\hline
\end{tabular}

\section{Copyrights}

Copyright for this article is retained by the author, with first publication rights granted to the journal.

This is an open-access article distributed under the terms and conditions of the Creative Commons Attribution license (http://creativecommons.org/licenses/by/4.0/). 